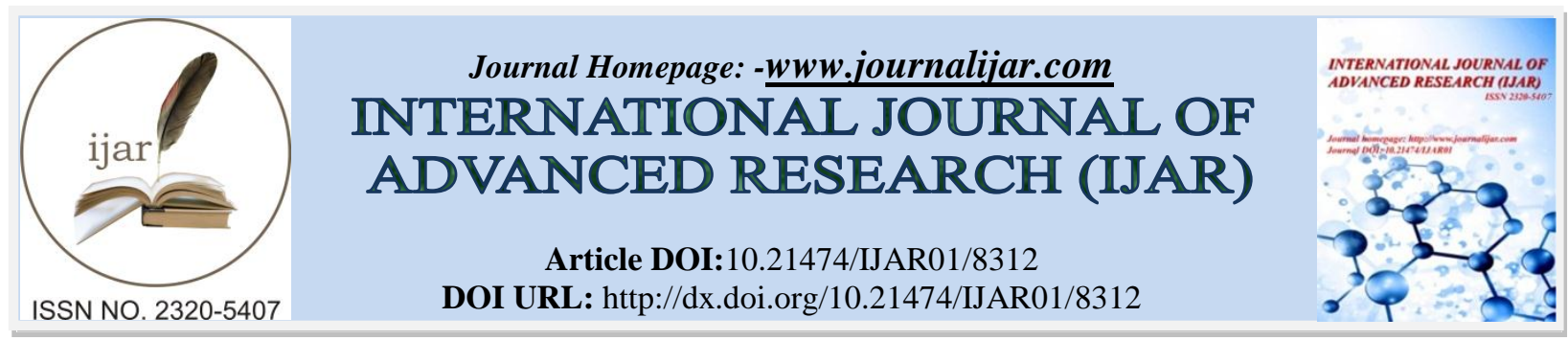

RESEARCH ARTICLE

\title{
ISOLATION OF MDR MICROORGANISMS FROM NATURAL SOURCES, STUDYING THEIR PLASMID PROFILE AND EVALUATION OF POTENCY FOR NATURAL TRANSFER OF MDR PROPERTY TO E. COLI DH5a
}

\section{Asha Salunke ${ }^{1}$, Hemal Makani ${ }^{1}$ and Murtadha Basheer Qori ${ }^{2}$.}

1. BioEra Life Sciences Pvt. Ltd., Mumbai-Bangalore Highway, Tathawade, Pune - 411 033, Maharashtra, India.

2. Department of Microbiology, Abeda Inamdar Senior College, Azam Campus, Pune - 411001, Maharashtra, India.

\section{Manuscript Info}

…......................

\section{Manuscript History}

Received: 04 November 2018

Final Accepted: 06 December 2018

Published: January 2019

\section{Keywords:}

Salmonella, Shigella, Pseudomonas, E. coli, Streptococcus, Staphylococcus, MDR, E. coli DH5a, Plasmid, Plasmid curing, Antibiotic resistance.

\section{Abstract}

The water samples from various sites on the banks of Pavana river, Pune were screened for presence of pathogenic Salmonella, Shigella, Pseudomonas, E. coli, Streptococcus and Staphylococcus. Some of the isolated pathogens showed resistance to ampicillin, streptomycin and erythromycin. To understand antibiotic resistance is Plasmid DNA borne, isolation of plasmid was carried out by alkaline lysis method, plasmid profile was analyzed by agarose gel electrophoresis and plasmids were cured from the isolates by growing them in nutrient broth containing $100 \mu \mathrm{g} / \mathrm{ml}$ ethidium bromide. Property of antibiotic resistance from MDR isolates was transferred to E. coli DH5a by growing E. coli DH5 $\alpha$ with cell free extract of MDR isolates.

Copy Right, IJAR, 2018,. All rights reserved.

\section{Introduction:-}

The Pavana River is a notable river crossing the cities of Pimpri-Chinchwad and Pune. Pavana River is life line of Pimpri-Chinchwad city and its water is used for domestic and agriculture purposes. Presently the city is under continuous stress due to population growth, industrial growth and waste generation. The growth of the city has been accompanied by severe pollution of the River. Different industrial sources can be held responsible for the pollution of the environment. In spite of Government regulations, lot of such waste is dumped around the cities and metropolis and deposited in natural water resources (Kamble and Patil, 2012, Kendre et al., 2017, Daware et al., 2015).

A diverse array of bacteria has also been reported in the river water. The biochemical diversity of microbes includes alkalophiles, chitin mobilizing bacteria and many more (Wagale et al., 2013, Nawani and Kapadnis, 2003). Coliforms, the indicatives of pathogens are also abundantly present in river water. Kazmi et al. (2013) estimated the most probable number of coliforms to be 230000 per $100 \mathrm{ml}$ of water. The water quality index of the river is at 38 which indicate 'bad' quality of water (Water quality index calculator; http://www.waterresearch.net/index.php/water-treatment/water-monitoring/monitoring-the-quality-of-surfacewaters).

More et al. (2014) stated that polluted water can cause the spread of diseases amongst people who use it for washing, cooking or bathing. Pollution also poses a great risk of contamination to ground water, affecting the people dependent on water supplies from wells and agricultural users. Water pollution has its most immediate effect on

Corresponding Author:-Asha Salunke.

Address:-BioEra Life Sciences Pvt. Ltd., Mumbai-Bangalore Highway, Tathawade, Pune - 411

033, Maharashtra, India. 
human health, through water borne diseases. The contamination of the environment with bacterial pathogens resistant to antimicrobial agents is a real threat not only as a source of disease but also as a source from which $\mathrm{R}$ plasmids can easily spread to other pathogens of diverse origins (Kruse and Sorum, 1994).

Contamination of river water with multiple drug resistant pathogens may lead to outbreaks of severe diseases which are more difficult and costlier to treat. More strains of pathogens have become antibiotic resistant, and some have become resistant to many antibiotics and chemotherapeutic agents, the phenomenon of multidrug resistance. As transfer of plasmid-encoded resistance to antimicrobial agents is significant public health concern, the possibility of transfer of resistance genes between bacteria in natural habitats has attracted attention (Kruse and Sorum, 1994). R factors may mediate resistance to as many as eight antibiotics simultaneously and confer resistance to heavy metals such as nickel, mercury, and cobalt. They are transmissible among gram-negative bacteria such as Escherichia coli, Salmonella, Shigella and to other unrelated bacteria such as Pseudomonas aeruginosa (Cooke, 1976).

This study focuses on the threat of MDR microorganisms in water bodies and transfer of MDR properties to naïve microorganisms present in the same environment.

\section{Materials And Method:-}

\section{Sample Collection}

200ml water samples were collected in sample collecting bottles from two different sites on the banks of Pavana river and transferred to the laboratory.

\section{Total Viable Count of Water sample}

To determine total viable count, each water sample was serially diluted to obtain dilution up to $10^{-9}$. $100 \mu 1$ of each dilutions of each water sample were spread on Sterile Nutrient agar plate. These plates were incubated at room temperature for 24 hour. Observations were recorded after the incubation.

\section{Total Count of Pathogenic Microorganisms}

To determine total viable count of pathogenic microorganisms viz., Salmonella, Shigella, Pseudomonas, Escherichia coli, Streptococcus, and Staphylococcus, $0.1 \mathrm{ml}$ of each water sample was spread on SS Agar, Cetrimide Agar, MacConkey Agar, Streptococcus Selection Agar and Mannitol Salt Agar. These plates were incubated at room temperature for 24 hour. Observations were recorded after the incubation.

\section{Screening for presence of pathogenic microorganisms}

$0.1 \mathrm{ml}$ of each water sample was spread on SS Agar plate for isolation of Salmonella and Shigella, on Cetrimide Agar plate for isolation of Pseudomonas, on MacConkey Agar plate for isolation of Escherichia coli, on Streptococcus selection agar plate for isolation of Streptococcus, on Mannitol Salt Agar plate for isolation of Staphylococcus. These plates were incubated at $37^{\circ} \mathrm{C}$ for 24 hours. After the incubation, plates were observed for bacterial growth.

\section{Antibiotic Sensitivity Test for selected Pathogenic microorganisms}

Isolated and selected cultures of E.coli, Streptococcus, Pseudomonas, Salmonella, Shigella and Staphylococcus were grown in $5 \mathrm{ml}$ of LB broth for $24 \mathrm{~h}$ at $37^{\circ} \mathrm{C}$. These selected pathogenic species were spread on LB media plate at high density. Discs impregnated with various antibiotics of standard concentrations were placed on these plates. The antibiotics used were Ampicillin $(10 \mu \mathrm{g} / \mathrm{ml})$, Chloramphenicol $(30 \mu \mathrm{g} / \mathrm{ml})$, Streptomycin $(10 \mu \mathrm{g} / \mathrm{ml})$, Erythromycin $(15 \mu \mathrm{g} / \mathrm{ml})$. The plates were then incubated overnight at room temperature and were observed next day. The clear zones surrounding the antibiotic discs were observed and their diameters were noted down for determination of antibiotic sensitivity. Standard Kirby-Bauer chart was used for the data analysis. A clear zone appears around that specific disc where the growth has been inhibited (zone of inhibition) whereas if an organism is resistant no clear zone of inhibition appears (Cooke, 1976).

\section{Plasmid DNA Isolation from Selected Pathogenic Species}

Isolated cultures of E. coli, Streptococcus, Pseudomonas, Salmonella, Shigella and Staphylococcus were grown in $5 \mathrm{ml}$ of $\mathrm{LB}$ broth for $24 \mathrm{~h}$ at $37^{\circ} \mathrm{C}$. Plasmid isolation of overnight grown MDR cultures was carried out by alkaline lysis method. In this protocol, plasmid DNA was prepared from MDR cultures by lysis via treatment with a solution containing sodium dodecyl sulfate (SDS) and sodium hydroxide. The mixture was then neutralized with sodium acetate. Most of the chromosomal DNA and bacterial proteins precipitated were removed by centrifugation. The 
reannealed plasmid DNA was then ethanol precipitated. RNA was removed by RNAseA treatment. The isolated plasmid was stored at $-20^{\circ} \mathrm{C}$. The presence of plasmid was checked by performing electrophoresis on $1 \%$ agarose gel (Salyers et al., 2004).

\section{Plasmid Curing from Selected Pathogenic Species}

$0.5 \mathrm{ml}$ of overnight grown cultures of E. coli, Streptococcus, Pseudomonas, Salmonella, Shigella and Staphylococcus was added in $4.5 \mathrm{ml} \mathrm{LB}$ broth containing $100 \mu \mathrm{g} / \mathrm{ml}$ concentration of Ethidium bromide as curing agent and incubated for $24 \mathrm{~h}$ at $37^{\circ} \mathrm{C}$ (Peterson and Bonomo, 2005).

After incubation, $0.1 \mathrm{ml}$ of each culture was spread on LB agar. Discs impregnated with various antibiotics of standard concentrations were placed on these plates. The antibiotics used were Ampicillin (10 $\mu \mathrm{g} / \mathrm{ml})$, Chloramphenicol $(30 \mu \mathrm{g} / \mathrm{ml})$, Streptomycin $(10 \mu \mathrm{g} / \mathrm{ml})$, Erythromycin $(15 \mu \mathrm{g} / \mathrm{ml})$. The plates were then incubated overnight at room temperature and were observed next day. The clear zones surrounding the antibiotic discs were observed and their diameters were noted down for determination of antibiotic sensitivity. Standard Kirby-Bauer chart was used for the data analysis. A clear zone appears around that specific disc where the growth has been inhibited (zone of inhibition) whereas if an organism is resistant no clear zone of inhibition appears (Elizabeth et al., 2016).

Transfer of naked DNA from Selected heat-killed MDR species to $E$. coli DH5a

Following steps were followed for transfer of naked DNA from selected heat-killed MDR species to E. coli DH5

1. Sterile Fourteen tubes consisting of $5 \mathrm{ml}$ of LB broth were taken.

2. Out of which 7 tubes were inoculated with $E$. coli $\mathrm{DH} 5 \alpha$ strain and incubated on shaker at $37^{\circ} \mathrm{C}$ at $100 \mathrm{rpm}$ for 5 to 6 hours (until it reaches log phase).

3. Overnight separately grown 6 MDR bacterial cultures viz., E. coli, Streptococcus, Pseudomonas, Salmonella, Shigella and Staphylococcus were heat-killed by heating at $80^{\circ} \mathrm{C}$ for $10 \mathrm{mins}$.

4. $\quad 0.1 \mathrm{ml}$ of each of heat-killed MDR cultures were inoculated separately in 6 tubes consisting of growing $E$. coli DH5 $\alpha$ from step $b$ and 6 tubes containing sterile LB Broth.

5. One tube of LB Broth was kept as positive control of $E$. coli DH5 $\alpha$ by inoculating the culture and one tube of LB Broth was kept as negative control for sterility check of media.

6. All the tubes were incubated overnight at $37^{\circ} \mathrm{C}$ in incubator.

\section{Antibiotic Sensitivity Test for $E$. coli DH5a after transfer of naked DNA}

Six tubes containing heat-killed MDR cultures inoculated in LB Broth consisting of growing E. coli DH5 $\alpha$ were spread on a LB Agar plate to get uniform loan growth. Discs impregnated with various antibiotics of standard concentrations were placed on these plates. The antibiotics used were Ampicillin (10 $\mu \mathrm{g} / \mathrm{ml})$, Chloramphenicol (30 $\mu \mathrm{g} / \mathrm{ml})$, Streptomycin $(10 \mu \mathrm{g} / \mathrm{ml})$, Erythromycin $(15 \mu \mathrm{g} / \mathrm{ml})$. The plates were then incubated overnight at room temperature and were observed next day. The clear zones surrounding the antibiotic discs were observed and their diameters were noted down for determination of antibiotic sensitivity. Standard Kirby-Bauer chart was used for the data analysis. A clear zone appears around that specific disc where the growth has been inhibited (zone of inhibition) whereas if an organism is resistant no clear zone of inhibition appears (Elizabeth et al., 2016).

\section{Results:-}

\section{Sample collection}

Two sites from Pavana River in Pimpri-Chinchwad were selected for the collection of samples to isolate microbial species showing MDR properties. Approximately $200 \mathrm{ml}$ of sample in sterile collection bottles was collected from each site.

\section{Microbial Characterization of water samples}

Total viable bacterial count was taken on sterile Nutrient Agar from both the water samples collected from Pavana River. The total viable count was expressed as CFU/ml of water sample. Site W1 - Chinchwadgaon (Pavana River) showed more total microbial count compared to Site W2 - Ravet Bridge (Pavana River). This also correlated with the total viable pathogenic microbial count for both water samples. E. coli, Salmonella, Pseudomonas and Shigella were more prevalent compared to Streptococcus and Staphylococcus. 
Antibiotic Sensitivity Test for selected Pathogenic microorganisms

Antibiotic sensitivity assay was performed using various antibiotic discs such as Ampicillin (A), Erythromycin (E), Chloramphenicol (C), Streptomycin (S). The results were observed after $24 \mathrm{hr}$ and the inferences are drawn by comparing the zone of inhibition values with the standard Kirby-Bauer chart values. All isolates showed resistance to Streptomycin while sensitivity to Chloramphenicol. Pseudomonas was the most resistant amongst all isolates.

\section{Plasmid DNA Isolation from Selected Pathogenic Species}

Plasmid isolation was performed by alkaline lysis method followed by its electrophoresis on $1 \%$ agarose gel. The gel was stained with Ethidium bromide and the bands were observed with the help of UV Transilluminator. E. coli showed maximum four plasmid DNA bands, while Staphylococcus, Salmonella, Shigella showed 2 plasmid DNA bands and Pseudomonas with 1 plasmid DNA band. Streptococcus did not show any visible plasmid DNA band. Molecular weights of plasmid DNA isolated from different isolates ranged from $20 \mathrm{~Kb}$ to $1.3 \mathrm{~Kb}$.

\section{Plasmid Curing from Selected Pathogenic Species}

Plasmid curing of MDR bacterial strains was carried out by using Ethidium bromide as the curing agent at the concentration of $100 \mu \mathrm{g} / \mathrm{ml}$. Cured pathogenic species was checked for possible loss of antibiotic resistance by Antibiotic Sensitivity assay. Antibiotic sensitivity assay was performed using various antibiotic discs such as Ampicillin (A), Erythromycin (E), Chloramphenicol (C), Streptomycin (S). The results indicated loss of antibiotic resistance by the isolates which were earlier resistant to antibiotics.

\section{Transfer of naked DNA from Selected heat-killed MDR species to E. coli DH5a}

MDR bacterial cultures were heat-killed and inoculated with growing E.coli DH5 $\alpha$ strain. The transfer of naked DNA from heat-killed MDR cultures to $E$. coli DH5 $\alpha$ strain was checked by plating the cultures and performing antibiotic sensitivity test. Results showed E. coli DH5 $\alpha$ similar pattern towards resistant to the antibiotics as shown by the naïve isolates.

\section{Discussion:-}

During this analysis approximately $200 \mathrm{ml}$ of two different water samples were collected, one from Chinchwadgaon (Pavana river) and other from Ravet Bridge site (Pavana river). Microbial analysis of water samples yielded information about the total microbial count which comments directly on portability of water. High levels of Pathogenic microorganisms were found in both the samples suggesting that the water sample from any of these sites is not fit for drinking purpose. Chinchwadgaon water sample showed highest number of Shigella, Salmonella, Pseudomonas and E. coli while Ravet bridge water sample showed highest number of Shigella, Salmonella and E. coli.

Salmonella isolate was found to be sensitive to Ampicillin and Chloramphenicol; whereas it was resistant to Streptomycin and Erythromycin. Santos (2001) discussed about Salmonella antibiotic resistance while studying Salmonella serotypes in humans, typhoid fever and enteritis, those can be modeled using Salmonella enteric serotype Typhimurium infections in mice and calves, respectively. The article reviews murine typhoid and bovine enteritis and discusses strengths, limitations and distinctive features of these animal models.

Shigella isolate was found to be sensitive to Ampicillin, Chloramphenicol and Erythromycin; it was intermediately resistant to Streptomycin. Our findings are similar to Suzuki (2001) who discussed the antibiotic resistance pattern of Shigella and their inter-cellular movements through cytoplasm to infect the adjuscent epithelial cells.

Pseudomonas isolate was found to be resistant to Ampicillin, Erythromycin and Chloramphenicol; it was intermediately resistant to Streptomycin. In a similar study conducted by Mena and Gerba (2009) it was found that Pseudomonas are highly versatile and can adapt to a wide range of habitats, and can even grow in distilled water. The review focuses majorly on the possible pathways and mechanisms that Pseudomonas adapts to overcome extreme environments such as high dosage of antibiotics.

E. coli isolate was found to be sensitive to Streptomycin and Chloramphenicol; it was intermediately resistant to Erythromycin whereas it was resistant to Ampicillin. In a study conducted by Salyers et al., (2004) explores a more sinister side of intestinal bacteria; their role as traffickers in antibiotic resistance genes. Evidence is accumulating to support the hypothesis that intestinal bacteria not only exchange resistance genes among themselves but might also 
interact with bacteria that are passing through the colon, causing these bacteria to acquire and transmit antibiotic resistance genes.

Streptococcus isolate was found to be sensitive to all the antibiotics mentioned here except Streptomycin. Similar findings were reported by Schuchat (1998) about the Heavy colonization of the genital tract with group B Streptococcus and increased risk that a woman will deliver a preterm low-birth weight infant. Early-onset infections (occurring at $<7$ days of age) are associated with much lower fatality than when they were first described, and their incidence is finally decreasing as the use of preventive antibiotics during childbirth increases among women at risk.

Staphylococcus isolate was found to be sensitive to Ampicillin, Chloramphenicol and Erythromycin; whereas it was resistant to Streptomycin. A recent study conducted by Corey (2009) explains in detail about the new antibiotics with proven efficacy against both susceptible and resistant strains of Staphylococcus particularly attractive for empirical therapy. The antimicrobial agents those are currently available for use in the treatment of both methicillinsusceptible and methicillin-resistant $S$. aureus bacteremia and the scientific evidence that forms a basis for the use of these agents.

Plasmid curing analysis of MDR bacterial isolates were performed in the presence of $100 \mu \mathrm{g} / \mathrm{ml}$ concentration of Ethidium bromide. The zone of clearance appeared to be bigger in diameter which may be due to the curing action of ethidium bromide against these isolates and this further confirms the fact that the resistant genes were harbored on the plasmids. Similar findings were reported in a study by Elizabeth et al., (2016) about the curing action of Ethidium bromide in plasmid curing analysis of bacteria isolated from two hospital environments. Plasmid curing analysis indicated that the antibiotic resistant gene is harbored on the plasmid. However, resistance of $P$. aeruginosa to ampicillin and $S$. aureus to penicillin and cefoxitin may be an indication that resistances of these organisms against antimicrobial agents are not only plasmid encoded. This confirms the assertion of most researchers that most microorganisms possess intrinsic resistance mechanisms which enable them to deactivate drug.

Transfer of naked DNA between MDR bacteria and E. coli DH5 $\alpha$ was checked by plating the cultures with antibiotic discs. There was no growth observed in plates with heat-killed MDR cultures whereas zones of clearance were observed in plates of $E$. coli DH5 $\alpha$ strain with heat-killed MDR cultures. The appearance of smaller zones of clearance indicated that the $E$. coli $\mathrm{DH} 5 \alpha$ strain could uptake the plasmid DNA from its environment. The foreign plasmid DNA was compatible with the host which led to its increased copy number resulting in antibiotic resistance. This result indicated that MDR bacteria are capable of transferring its antibiotic resistance property to the microorganisms in their natural habitat. Similar study was reported by Cooke (1976) who studied that the isolates resistant to streptomycin or tetracycline were capable of transferring all or part of their resistance pattern to an antibiotic-susceptible strain of Escherichia coli K-12.

From above points we can conclude that the antibiotic resistance of these microorganisms is increasing day by day and their presence in the river water at varied locations indicates highly polluted status of the river water. This can be an alarming signal to the threat to the population residing on the banks of these rivers. The contamination of the environment with bacterial pathogens resistant to antimicrobial agents is a real threat not only as a source of disease but also as a source from which R plasmids can easily spread to other pathogens of diverse origins.

Table 1:-Total Microbial analysis of Chinchwadgaon water sample and Ravet Bridge water sample

\begin{tabular}{|l|l|}
\hline Sample & Total Viable Count (CFU/ml) \\
\hline W1- Chinchwadgaon (Pavana River) & $4.56 \times 10^{5}$ \\
\hline W2-Ravet Bridge (Pavana River) & $2.27 \times 10^{5}$ \\
\hline
\end{tabular}

Table 2:-Pathogenic Microbial analysis of Chinchwadgaon Water sample and Ravet Bridge water sample

\begin{tabular}{|l|l|l|}
\hline \multirow{2}{*}{ Pathogen } & Total Viable Pathogenic Microbial Count (CFU/ml) \\
\cline { 2 - 3 } & W1- Chinchwadgaon (Pavana River) & W2-Ravet Bridge (Pavana River) \\
\hline $\begin{array}{l}\text { Shigella } \\
\text { Salmonella }\end{array}$ & $4.67 \times 10^{3}$ & 44 \\
\hline Pseudomonas & $1.15 \times 10^{3}$ & 19 \\
\hline E. coli & $1.15 \times 10^{4}$ & $2.50 \times 10^{3}$ \\
\hline
\end{tabular}




\begin{tabular}{|l|l|l|}
\hline Streptococcus & 51 & 23 \\
\hline Staphylococcus & 75 & 45 \\
\hline
\end{tabular}

Table 3:-Antibiotic sensitivity test of natural isolates from river water samples

\begin{tabular}{|l|l|l|l|l|}
\hline \multirow{2}{*}{ Pathogen } & Diameter of zone of inhibition (in mm) and Inference & \\
\cline { 2 - 5 } & Ampicillin & Chloramphenicol & Streptomycin & Erythromycin \\
\hline Shigella & $30[\mathrm{~S}]$ & $23[\mathrm{~S}]$ & $12[\mathrm{I}]$ & $6[\mathrm{R}]$ \\
\hline Salmonella & $20[\mathrm{~S}]$ & $19[\mathrm{~S}]$ & $8[\mathrm{R}]$ & $6[\mathrm{R}]$ \\
\hline Pseudomonas & $8[\mathrm{R}]$ & $17[\mathrm{I}]$ & No Zone $[\mathrm{R}]$ & $5[\mathrm{R}]$ \\
\hline E. coli & $7[\mathrm{R}]$ & $40[\mathrm{~S}]$ & $17[\mathrm{~S}]$ & $14[\mathrm{I}]$ \\
\hline Streptococcus & $28[\mathrm{~S}]$ & $26[\mathrm{~S}]$ & $10[\mathrm{R}]$ & $30[\mathrm{~S}]$ \\
\hline Staphylococcus & $31[\mathrm{~S}]$ & $20[\mathrm{~S}]$ & $2[\mathrm{R}]$ & $21[\mathrm{~S}]$ \\
\hline
\end{tabular}

Table 4:-Antibiotic sensitivity test of isolates after plasmid curing

\begin{tabular}{|l|l|l|l|l|}
\hline \multirow{2}{*}{ Pathogen } & \multicolumn{4}{l|}{ Diameter of zone of inhibition (in mm) and Inference } \\
\cline { 2 - 5 } & Ampicillin & Chloramphenicol & Streptomycin & Erythromycin \\
\hline Shigella & $40[\mathrm{~S}]$ & $28[\mathrm{~S}]$ & $20[\mathrm{~S}]$ & $10[\mathrm{I}]$ \\
\hline Salmonella & $26[\mathrm{~S}]$ & $22[\mathrm{~S}]$ & $18[\mathrm{~S}]$ & $8[\mathrm{I}]$ \\
\hline Pseudomonas & $20[\mathrm{~S}]$ & $22[\mathrm{~S}]$ & $18[\mathrm{~S}]$ & $14[\mathrm{~S}]$ \\
\hline E. coli & $17[\mathrm{~S}]$ & $52[\mathrm{~S}]$ & $22[\mathrm{~S}]$ & $20[\mathrm{~S}]$ \\
\hline Streptococcus & $32[\mathrm{~S}]$ & $28[\mathrm{~S}]$ & $18[\mathrm{~S}]$ & $29[\mathrm{~S}]$ \\
\hline Staphylococcus & $35[\mathrm{~S}]$ & $25[\mathrm{~S}]$ & No Zone $[\mathrm{R}]$ & $25[\mathrm{~S}]$ \\
\hline
\end{tabular}

Table 5:-Antibiotic sensitivity Test of E. coli DH5 $\alpha$ after incubation with heat killed cells extracts of natural isolates

\begin{tabular}{|c|c|c|c|c|}
\hline \multirow[t]{2}{*}{ Pathogen } & \multicolumn{4}{|c|}{ Diameter of zone of inhibition (in $\mathrm{mm}$ ) and Inference } \\
\hline & Ampicillin & Chloramphenicol & Streptomycin & Erythromycin \\
\hline $\begin{array}{l}\text { E. coli DH5 } \alpha+\text { Heat } \\
\text { Killed Shigella }\end{array}$ & $26[S]$ & $12[\mathrm{R}]$ & $14[\mathrm{I}]$ & $6[\mathrm{R}]$ \\
\hline $\begin{array}{l}\text { E. coli DH5 } \alpha+\text { Heat } \\
\text { Killed Salmonella }\end{array}$ & $25[\mathrm{~S}]$ & $12[\mathrm{~S}]$ & $8[\mathrm{R}]$ & $4[\mathrm{R}]$ \\
\hline $\begin{array}{l}\text { E. coli DH5 } \alpha+\text { Heat } \\
\text { Killed Pseudomonas }\end{array}$ & $10[\mathrm{R}]$ & $20[\mathrm{~S}]$ & $6[\mathrm{R}]$ & $12[\mathrm{R}]$ \\
\hline $\begin{array}{l}\text { E. coli } \text { DH } 5 \alpha+\text { Heat } \\
\text { Killed } E \text {. coli }\end{array}$ & $8[\mathrm{R}]$ & $38[\mathrm{~S}]$ & $20[\mathrm{~S}]$ & $18[\mathrm{~S}]$ \\
\hline $\begin{array}{l}\text { E. coli DH5 } \alpha+\text { Heat } \\
\text { Killed Streptococcus }\end{array}$ & $30[\mathrm{~S}]$ & $30[\mathrm{~S}]$ & $8[\mathrm{R}]$ & $28[\mathrm{~S}]$ \\
\hline $\begin{array}{l}\text { E. coli DH5 } \alpha+\text { Heat } \\
\text { Killed Staphylococcus }\end{array}$ & $26[S]$ & $24[\mathrm{~S}]$ & $6[\mathrm{R}]$ & $16[S]$ \\
\hline
\end{tabular}

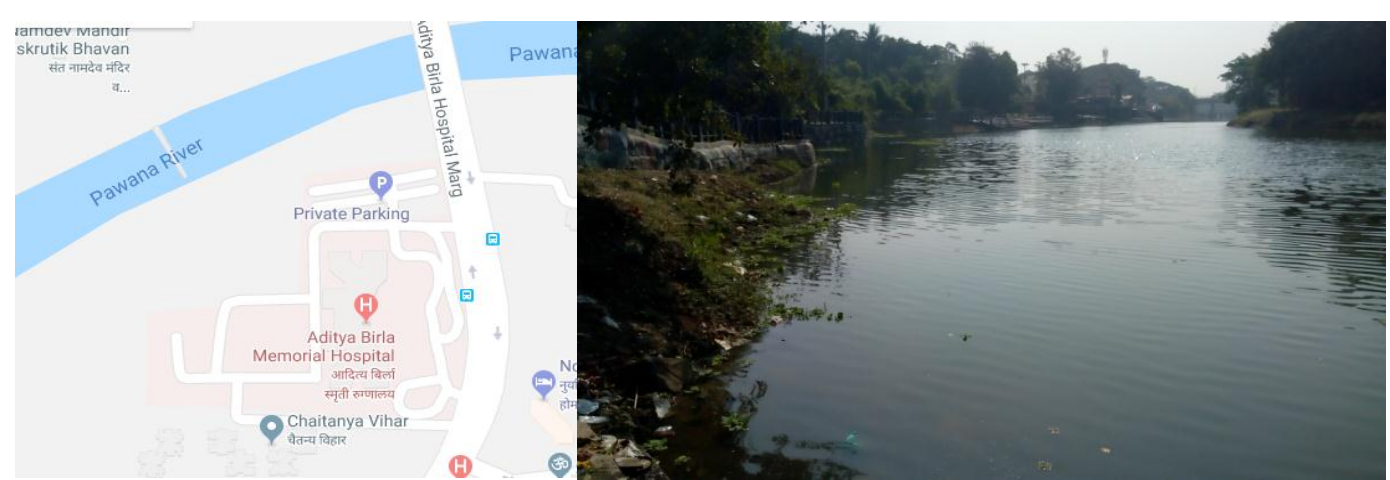

Image 1:-Water Sample collection site W1- Chinchwadgaon (Pavana River) 


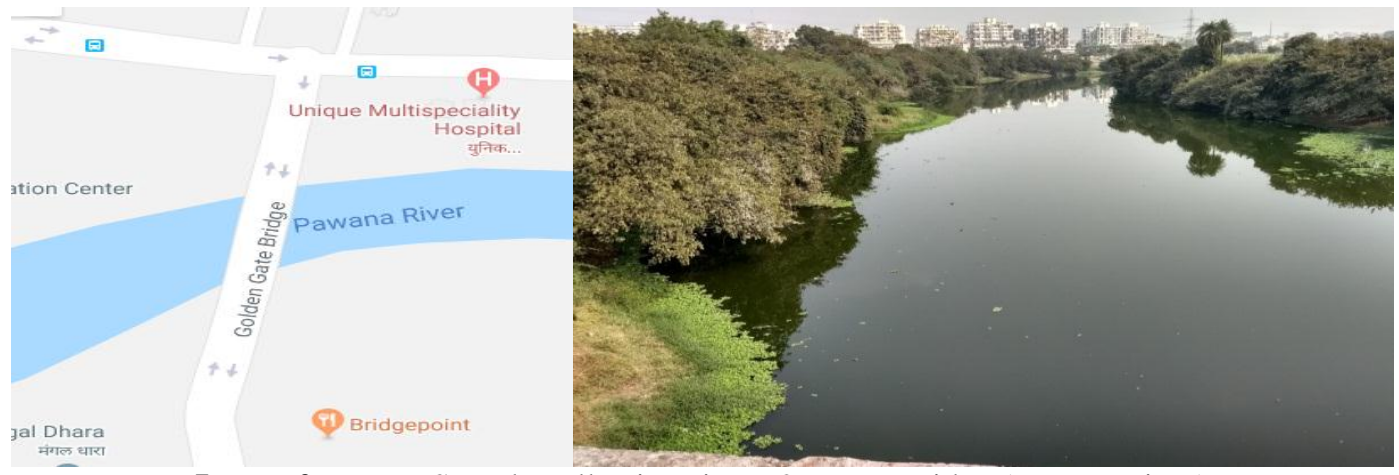

Image 2:-Water Sample collection site W2-Ravet Bridge (Pavana River)
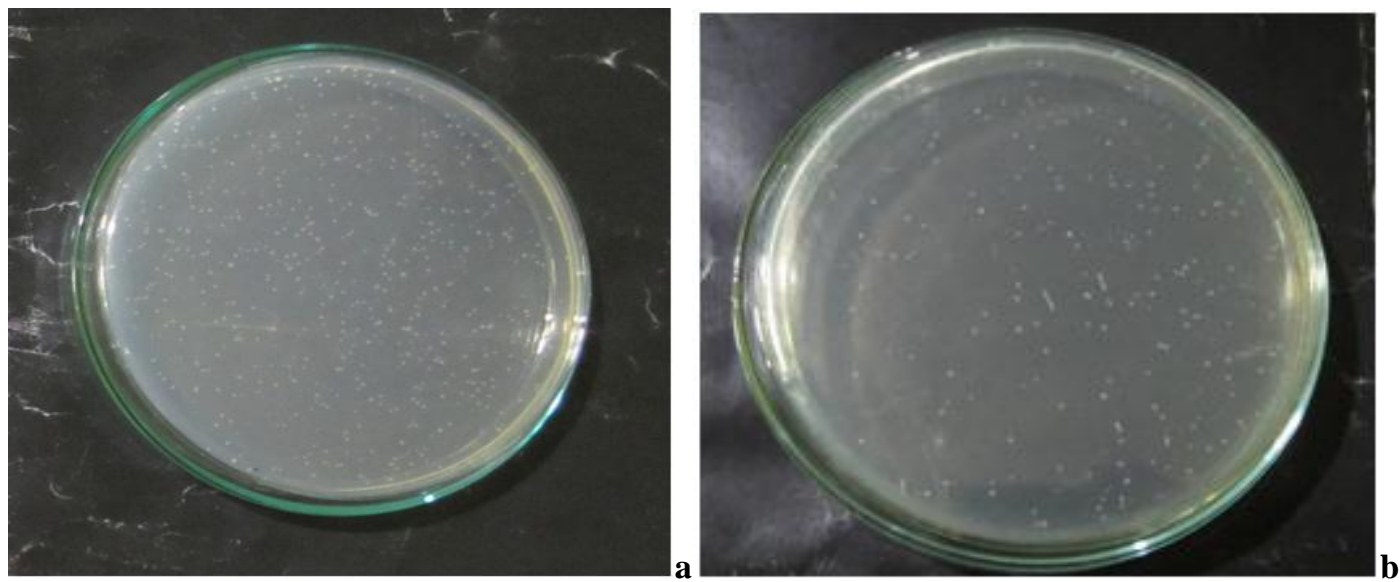

Image 3:-Total viable count, a. W1 - Chinchwadgaon river water sample, b. W2 - Ravet Bridge

a

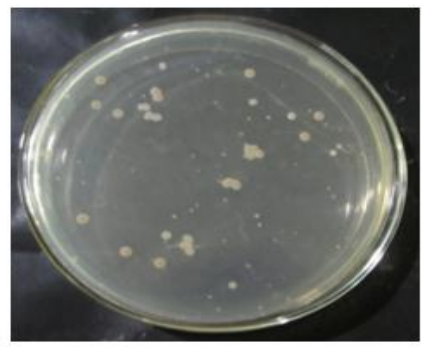

b

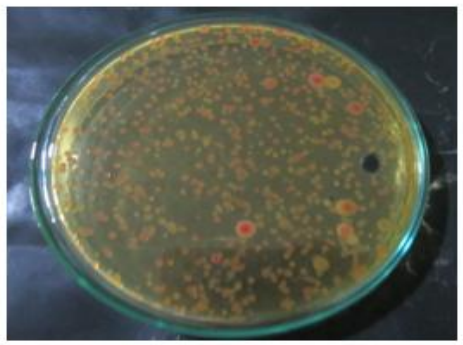

c

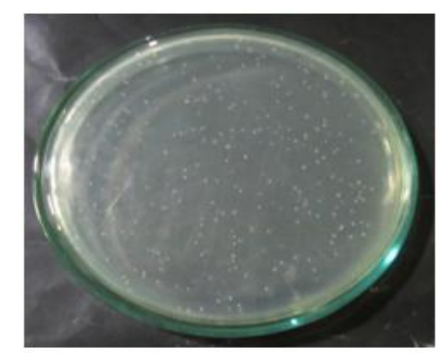

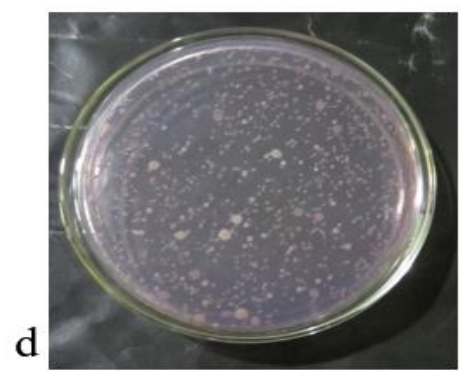

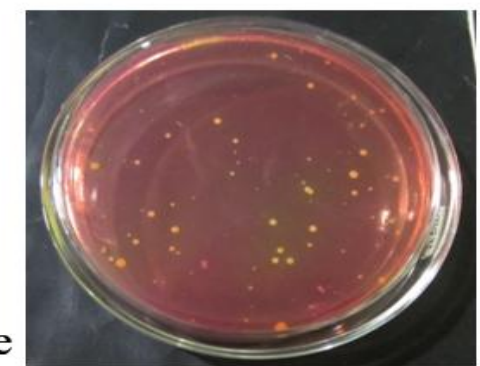

Image 4:-Pathogenic microorganisms load in Chinchwadgaon river water sample, a: Pseudomonas on Cetrimide agar, b: Shigella and Salmonella on SS agar, c: Streptococcus on Streptococcus selection agar, d: E. coli on MacConkey agar, e: Staphylococcus on MSA 
a

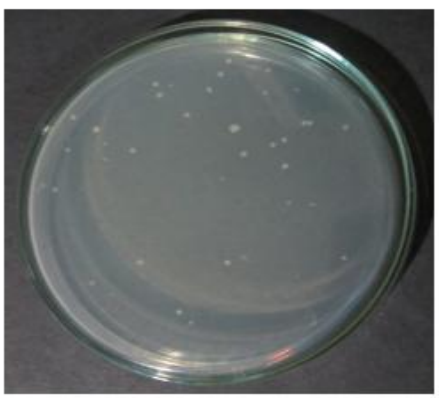

b

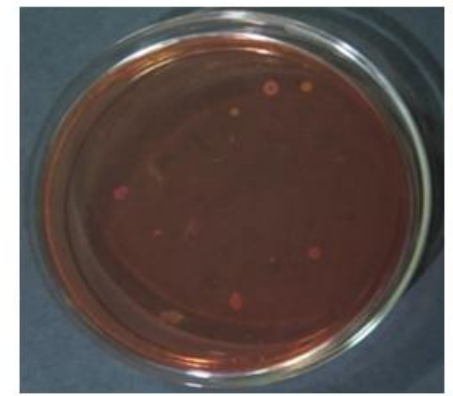

C

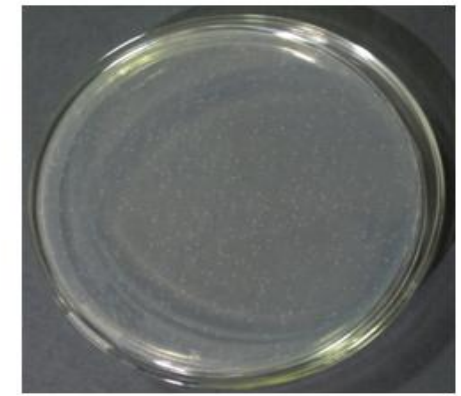

d

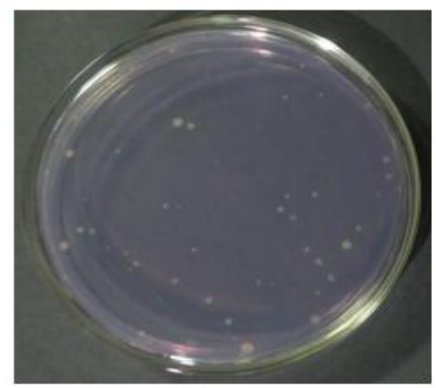

e

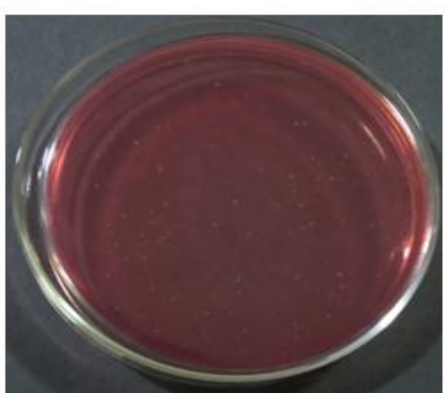

Image 5:-Pathogenic microorganisms load in Ravet river water sample, a: Pseudomonas on Cetrimide agar, b: Shigella and Salmonella on SS agar, c: Streptococcus on Streptococcus selection agar, d: E. coli on MacConkey agar, e: Staphylococcus on MSA
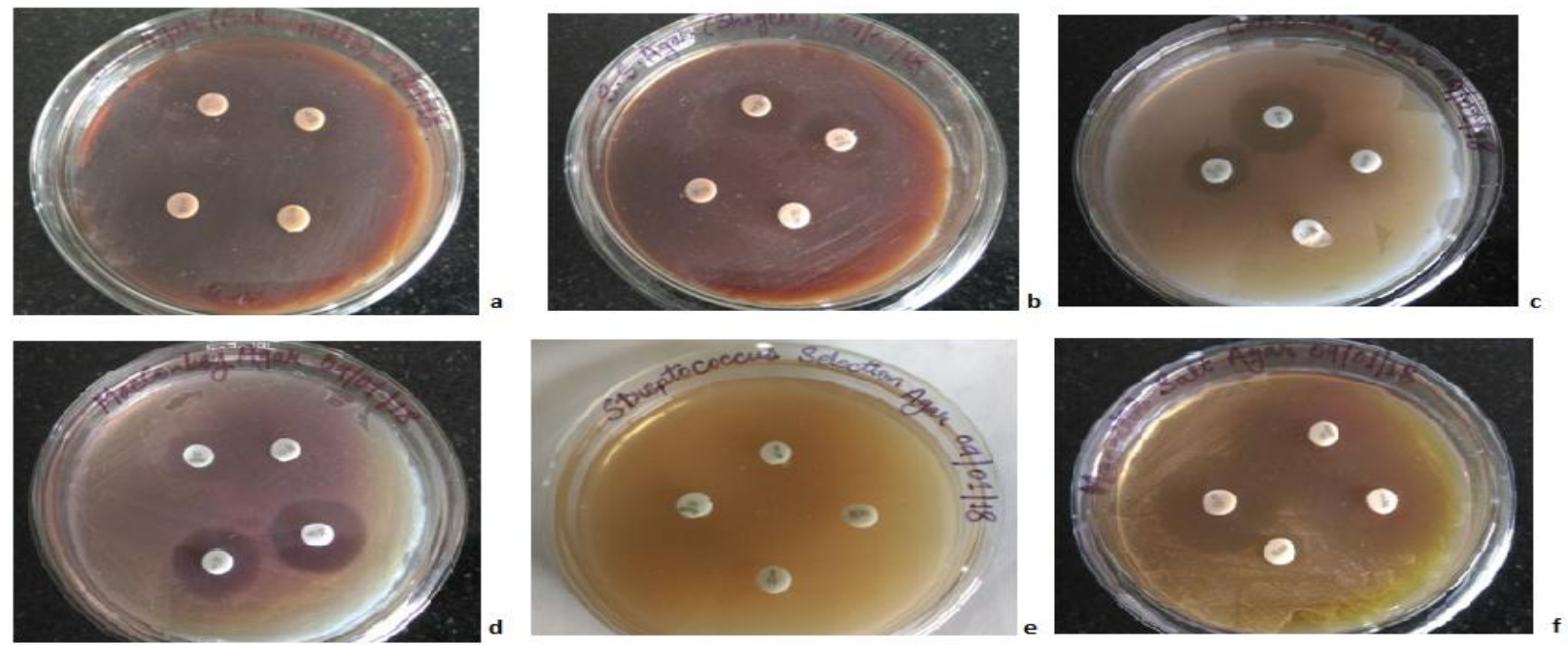

Image 6:-Antibiotic sensitivity test of natural isolates from river water, a: Salmonella b: Shigella c: Pseudomonas d: E. coli, e: Streptococcus, f: Staphylococcus 


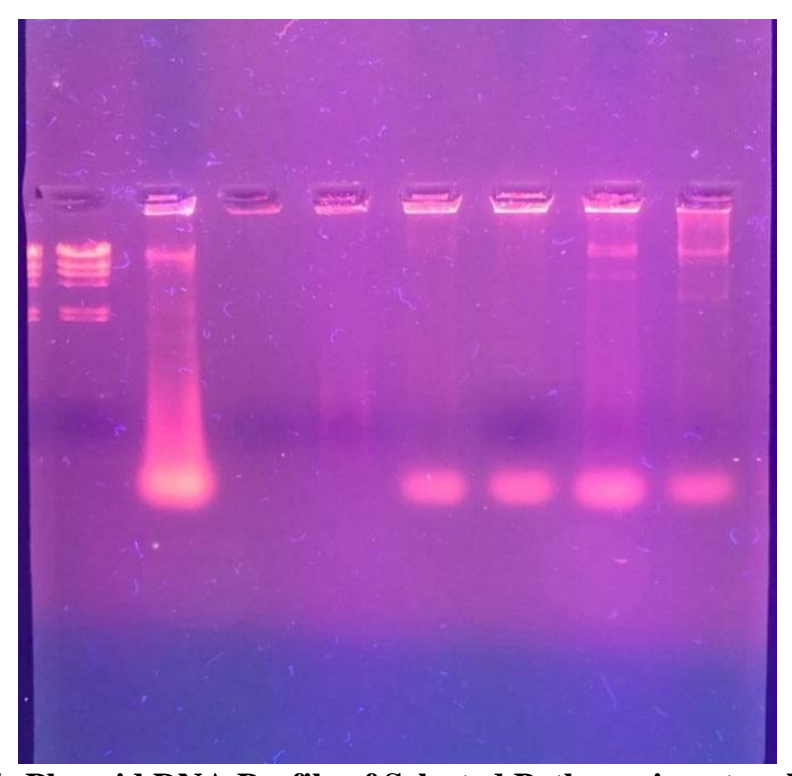

\section{Image 7:-Plasmid DNA Profile of Selected Pathogenic natural isolates}

Lane 1 : Standard molecular weight marker lane with molecular weights $25 \mathrm{~kb}, 22 \mathrm{~kb}, 18 \mathrm{~kb}, 15 \mathrm{~kb}, 8 \mathrm{~kb}$, and $5 \mathrm{~kb}$. Lane 2: Plasmid Profile E. coli with 4 plasmid bands of molecular weight $20 \mathrm{~kb}, 10 \mathrm{~kb}$, and $3 \mathrm{~kb}$ and $2.2 \mathrm{~kb}$.

Lane 3: Empty

Lane 4 : Plasmid Profile Staphylococcus with 2 plasmid bands of molecular weight $3 \mathrm{~kb}$, and $1.3 \mathrm{~kb}$.

Lane 5 : Plasmid Profile Pseudomonas with 1 plasmid bands of molecular weight $3.5 \mathrm{~kb}$.

Lane 6 : Plasmid Profile Streptococcus with no visible plasmid bands.

Lane 7 : Plasmid Profile Salmonella with 2 plasmid bands of molecular weight $17 \mathrm{~kb}$, and $6 \mathrm{~kb}$.

Lane 8 : Plasmid Profile Shigella with 2 plasmid bands of molecular weight $16 \mathrm{~kb}$, and $5 \mathrm{~kb}$.
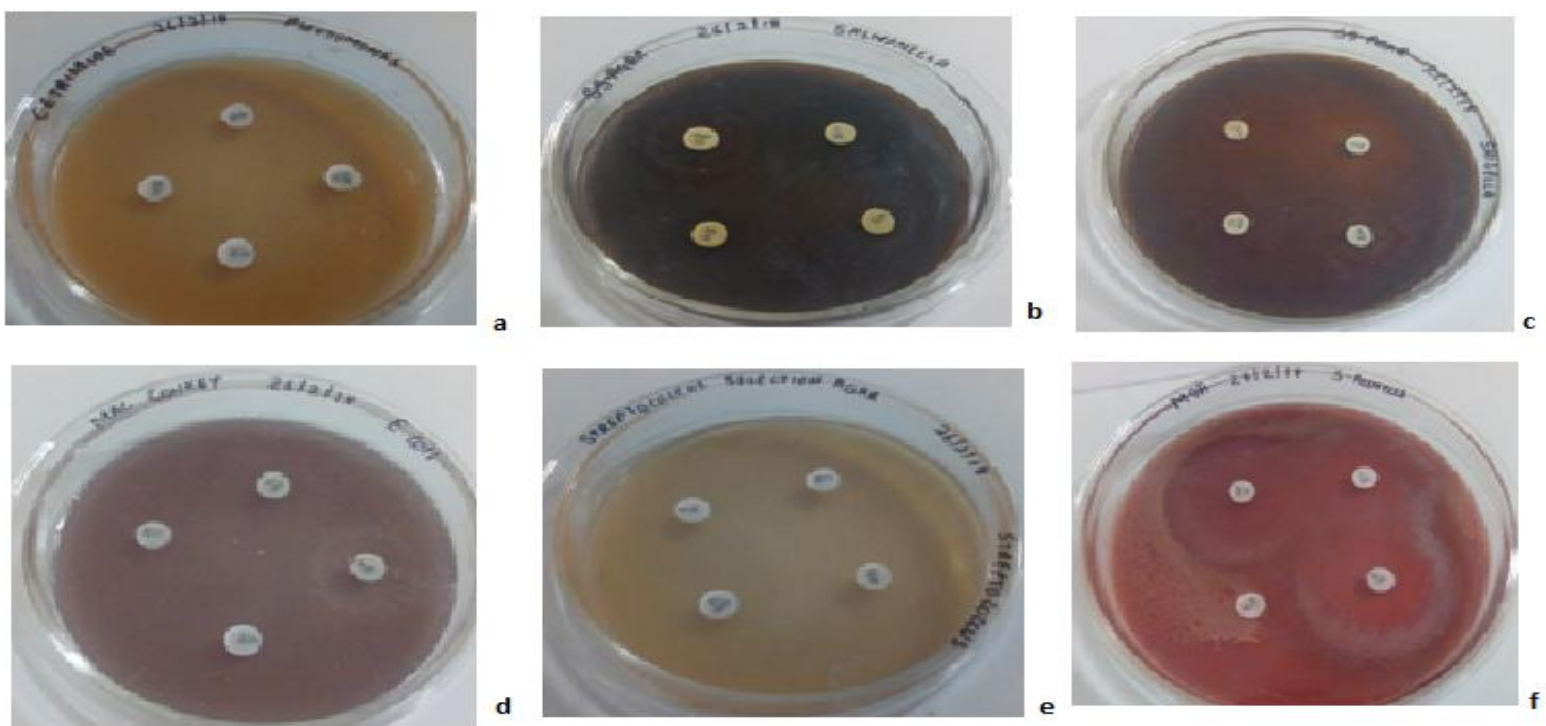

Image 8:-Antibiotic sensitivity test of natural isolates after plasmid DNA curing, a:Pseudomonas, b: Salmonella, c: Shigella, d: E. coli, e: Streptococcus, f: Staphylococcus 

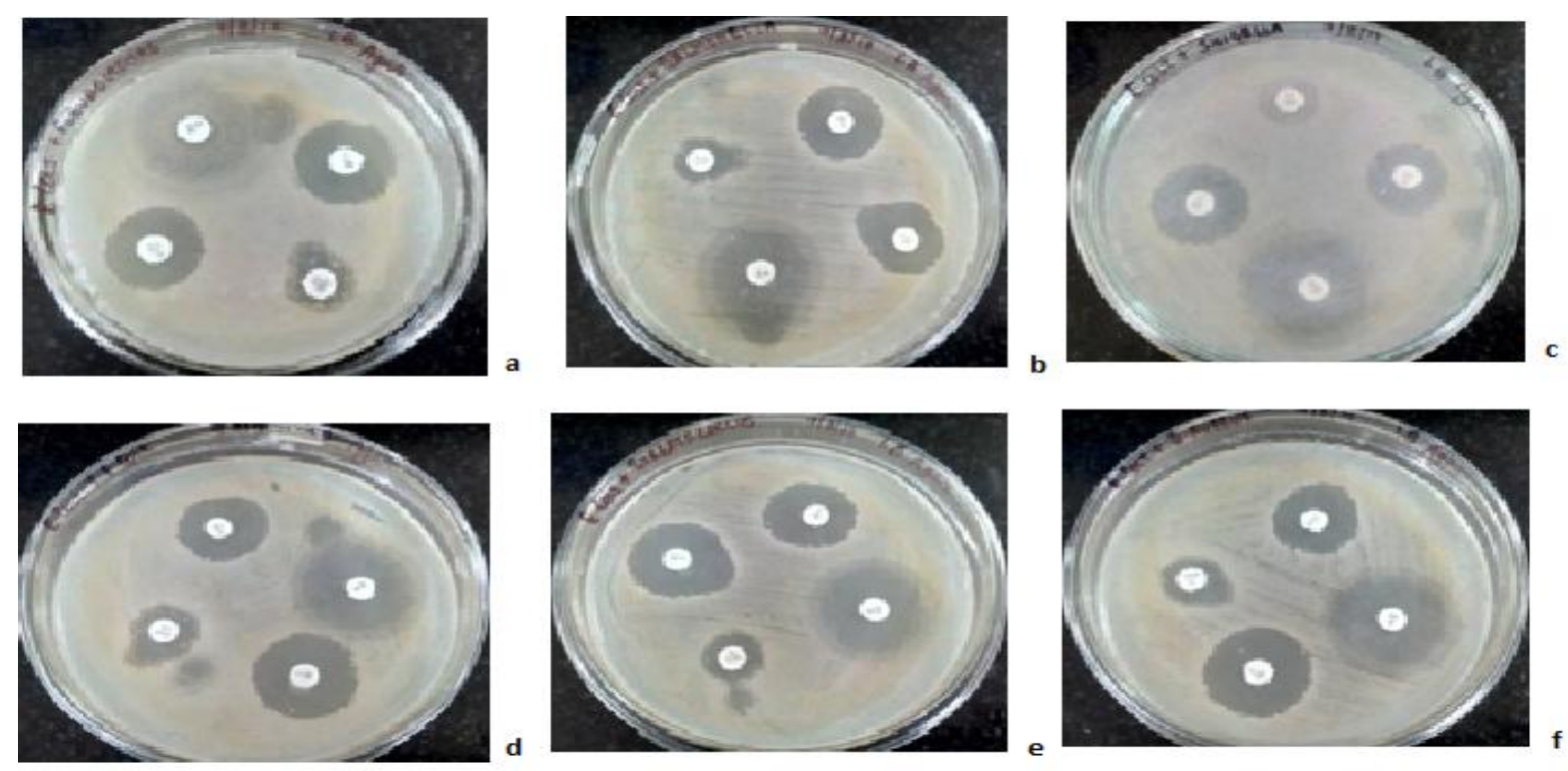

Image 9:-Antibiotic sensitivity test of $E$. coli DH5 $\alpha$ after incubation with heat killed cells extracts of natural isolates, a: E. coli DH5 $\alpha+$ Heat Killed MDR Pseudomonas, b: E. coli DH5 $\alpha+$ Heat Killed MDR Salmonella, c: $E$. coli DH5 $\alpha$ + Heat Killed MDR Shigella, d: E. coli DH5 + + Heat Killed MDR E. coli, e: E. coli DH5 $\alpha+$ Heat Killed MDR Streptococcus, f: E. coli DH5 $\alpha+$ Heat Killed MDR Staphylococcus

\section{References:-}

1. Kamble, R. and Patil D. (2012): Artificial floating island: solution to river water pollution in India. Case study: Rivers in Pune city. International proceedings of chemical, biological and environmental engineering. 41: 136140.

2. Kendre, L.S., Gawande, S.M., Pawar, A. (2017): Study of Physico-Chemical Characteristics of Pavana River: Review. International Journal of Engineering Research. 6(4): 216-219.

3. Daware, V., Patil, R., Gade, W. (2015): Isolation, identification and characterization of heavy metal tolerant bacteria from Mula river, Pune, Maharashtra, India. Trends Biotechnol Res. 4(1): 1- 10.

4. Wagale, A., Pawar, N., Berde, J.A., Sapre, V.R. (2013): A study to isolate the Alkaliphiles in the Mula Mutha River of Pune. Asian Journal of Multidisciplinary Studies. 1(1): 9-11.

5. Nawani, N. N. and Kapadnis, B.P. (2003): Chitin degrading potential of bacteria from extreme and moderate environment. Indian journal of experimental biology. 41: 448-454.

6. Kazmi, A.A., Bhatia, A., Shaida, A., Sharma, M., Stark, M., Trivedi, R. C. (2013): A short screening study on water quality of Indian rivers and lakes. J. Indian Water Resour. Soc. 33(3): 28-33.

7. More, A. B., Chavan, C. S., Gurung, A., Sarwade, P., Chaudhari, S., Vyas, R. (2014): Water Quality Status of Mula-Mutha River. 3(4): 75-77.

8. Kruse, H. and Henning, S. (1994): Transfer of Multiple Drug Resistance Plasmids between Bacteria of Diverse Origins in Natural Microenvironments. Applied and Environmental Microbiology. 60(11): 4015-4021.

9. Cooke, M.D. (1976): Antibiotic Resistance Among Coliform and Fecal Coliform Bacteria Isolated from Sewage, Seawater, and Marine Shellfish. Antimicrobial agents and chemotherapy. 9(6): 879-884.

10. Salyers, A.A., Gupta, A., Wang, Y. (2004): Human intestinal bacteria as reservoirs for antibiotic resistance genes. Trends Microbiol. 12(9): 412-6.

11. Paterson, D.L. and Bonomo R.A. (2005): Extended-spectrum beta-lactamases: a clinical update. Clin. Microbiol. Rev. 18(4): 657-86.

12. Elizabeth, N., Clement, I., Uwem, O. (2016): Plasmid Profile Analysis and Curing of Multidrug resistant Bacteria Isolated from Two Hospital Environments in Calabar Metropolis, Nigeria. Asian Journal of Medicine and Health. 1(1): 1-11.

13. Santos, L., Zhang, S., Tsolis, R.N., Kingsley, R.L., Adams, L.G., Baumler, A.D. (2001): Animal models of Salmonella infections: enteritis versus typhoid fever. Microbes and Infection. 3: 1335-1344.

14. Suzuki, T. and Chihiro, S. (2001): Molecular basis of the intracellular spreading of Shigella. Infection and Immunity. 69(10): 5959-66. 
15. Mena, K.D. and Gerba, C.P. (2009): Risk assessment of Pseudomonas aeruginosa in water. Rev Environ Contam Toxicol. 201: 71-115.

16. Schuchat, A. (1998): Epidemiology of Group B Streptococcal Disease in the United States: Shifting Paradigms. Clinical Microbiology Reviews. 11(3): 497-513.

17. Corey, G.R. (2009): Staphylococcus aureus Bloodstream Infections: Definitions and Treatment. Clinical Infectious Diseases. 48: 254-9. 